Research Article

Open Access

\title{
Unidentified Polymorphism in IP-10/CXCL10 Gene linked to Type 1 Diabetes
}

\section{Teodora Daneva ${ }^{*}$}

Institute of Biology and Immunology of Reproduction, Bulgarian Academy of Scineces, Sofia, Bulgaria

\section{Article Info}

\section{*Corresponding author:}

\section{Teodora Daneva}

Institute of Biology and Immunology of Reproduction

Bulgarian Academy of Scineces

Sofia

Bulgaria

E-mail: danevadoki@abv.bg

Received: May 16, 2018

Accepted: July 5, 2018

Published: July 10, 2018

Citation: Daneva T. Unidentified Polymorphism in $\mid \mathrm{p}-10 / \mathrm{Cxcl} 10$ Gene linked to Type 1 Diabetes. Madridge J Diabetes. 2018; 2(1): 51-54.

doi: $10.18689 / \mathrm{mjd}-1000110$

Copyright: (c) 2018 The Author(s). This work is licensed under a Creative Commons Attribution 4.0 International License, which permits unrestricted use, distribution, and reproduction in any medium, provided the original work is properly cited.

Published by Madridge Publishers

\begin{abstract}
The development of insulin dependent type 1 diabetes (T1D) is considered to be an autoimmune proinflammatory process mediated by T-cell destruction of pancreatic beta cells. It is believed to be triggered by some environmental factors and human enteroviruses are among the candidates. After infection the virus enters beta cells and triggers the expression of immunological factors as chemokines, interferons, interleukins which attract and activate autoreactive immune cells. The attracted and activated immune cells destroy infected beta cells. The viruses may trigger T1D, but the genes play important role in this process. Improved knowledge of gene polymorphisms of chemokines and their receptors could be useful to predict the onset of diabetes and define its progression.
\end{abstract}

When searching for polymorphisms in the genes encoding chemokines MIG/CXCL9, IP-10/CXCL10 and I-TAC/CXCL11 I found a difference in the IP-10 gene between patients with type 1 diabetes and control patients.

Identification of this polymorphism would give more light and explanation for the reason and mechanism by which some individuals develop autoimmune diabetes. This knowledge would help us develop a strategy for prediction and prevention of T1D.

These investigations will contribute to fighting diabetes on national and international level. The chemokine IP-10 expressed from pancreatic beta cells and its receptor CXCR3, expressed on the surface of immune cells are of interest as a predictive marker for the risk assessment of the autoimmune destruction of beta cells.

By screening the people for this polymorphism we may be able to identify the predisposed to T1D individuals in early childhood and prevent the development of T1D by trying different experimental preventive therapies and approaches.

Keywords: IP-10; Pancreatic beta cells; Type 1 diabetes.

\section{Introduction}

Type 1 diabetes (T1D) is still a mystery for doctors and scientists. The causes and mechanisms triggering this disease remain unknown. The development of type 1 diabetes is considered to be an autoimmune proinflammatory process mediated by T-cell destruction of pancreatic beta cells. It is believed to be triggered by some environmental factors and human enteroviruses are among the candidates. After infection, the virus enters beta cells and triggers the expression of immunological factors as chemokines, interferons, interleukins which attract and activate autoreactive immune cells. The attracted and activated immune cells destroy infected beta cells.

Chemokines are a family of small cytokines, or signaling proteins secreted by cells. Their name is derived from their ability to induce directed chemotaxis in nearby responsive leukocytes. They are chemotactic cytokines. Chemokines are all approximately 8-10 KD in mass and have four cysteine residues in conserved locations that are key to forming their 
3-dimensional shape. They are secondary pro-inflammatory mediators that are induced by primary pro-inflammatory mediators such as interferon gamma (IFN- $\gamma$ ) interleukin-1 (IL1) or tumor necrosis factor (TNF). There are two major chemokine sub-families based upon the position of cysteine residues, i.e., CXC and CC. All members of the CXC chemokine sub-family have an intervening amino acid between the first two cysteines; members of the CC chemokine sub-family have two adjacent cysteines.

Among CXC chemokines are CXCL9 (MIG), CXCL10 (IP-10), CXCL11 (I-TAC), CXCL12 (SDF1) and others.

The gene for $\mathrm{CXCL} 10$ is located on human chromosome 4 in a cluster among several other CXC chemokines.

CXCL10 is secreted by several cell types in response to IFN- $\gamma$. These cell types include monocytes, endothelial cells and fibroblasts. CXCL10 has been attributed to several roles, such as chemoattraction for monocytes/macrophages, $T$ cells, NK cells, and dendritic cells, promotion of T cell adhesion to endothelial cells, antitumor activity, and inhibition of bone marrow colony formation and angiogenesis.

This chemokine elicits its effects by binding to the cell surface chemokine receptor CXCR3 and TLR4.

Over the last decade more data has been accumulated about elevated serum levels and increased expression of IP$10 / C X C L 10$ in pancreatic islets before and in the early stages of type 1 diabetes development. Some authors assume that serum levels of IP-10 are more reliable indicator for the development of autoimmune diabetes than anti-insulin autoantibodies and anti-islet autoantibodies [1,2]. According to Xin. et al. Serum levels of IP-10 in children with T1D are elevated compared to controls in the onset of disease and decrease within the time, and it is not linked to the presence of anti islet autoantibodies [3].

Shingihara et al. also measured elevated IP-10 and CXCR3 expression levels before diabetes in diabetic mice, and suggest that the serum levels of IP-10 may be an accurate indicator of the development of T1D [4]. Li et al. establish a very strong expression of IP-10 in the islets of Langerhans of NOD mice compared to control mice and that IP-10 is produced by beta cells and is stored in the cytoplasm of these cells and plays an important role in the pathogenesis of type 1 diabetes, attracting immune cells that infiltrate the pancreatic islets [5].

IP-10 and CXCR3 are of interest as a predictive marker for the risk assessment of the autoimmune destruction of beta cells. Uno et al. after the study of 5 patients with diabetes type 1 and 5 control patients for anti-islet antibodies, GAD, IP-10 and CXCR3 have concluded that mainly the interaction between IP-10 and CXCR3 contributes to the selective destruction of beta cells [6]. Coppieters et al. reported that experimental obstruction of the interaction between IP-10 and CXCR3 inhibits invasion of cytotoxic T lymphocytes and protects islet beta cells from death [7]. There are claims and proves? that type 1 diabetes is the result of pro-inflammatory process mainly via IP-10 and CXCR3, but as a result of local viral infection $[8,9]$. According to the opinion of Shimada et al. and Antonelli et al. CXCL10/CXCR3 system plays a critical role in the autoimmune beta cell destruction. Viral beta cell infections induce cytokines and CXCL10 expression, inducing beta cell failure in T1D. Blocking CXCL10 in new onset diabetes seems a possible approach for T1D treatment $[10,11]$.

Some experimental data of other authors show that CXCL10 impairs $\beta$ cell function and viability in diabetes through TLR4 signaling [12].

\section{Materials and Methods}

Blood samples were collected during routine clinical investigations.

\section{Genomic DNA Isolation}

\section{Preparation of hypotonic lysis buffer}

$55 \mathrm{~g}$ sucrose was dissolved in $400 \mathrm{ml} \mathrm{H}_{2} \mathrm{O}$ and $5 \mathrm{ml}$ of $1 \mathrm{M}$ Tris- $\mathrm{HCl}(\mathrm{pH} 8), 5 \mathrm{ml}$ triton $\mathrm{X}-100$, and $2,5 \mathrm{ml} 1 \mathrm{M} \mathrm{MgCl}_{2}$, were added to a final volume of $500 \mathrm{ml}$.

\section{Preparation of nuclei resuspension buffer}

$1,5 \mathrm{ml}$ of $5 \mathrm{M} \mathrm{NaCl}$ and $4,8 \mathrm{ml}$ of $0,5 \mathrm{M}$ EDTA were added to a final volume of $100 \mathrm{ml}$. Preparation of proteinase $\mathrm{K}$ solution. $100 \mathrm{mg}$ proteinase $\mathrm{K}$ was dissolved in $10 \mathrm{ml} \mathrm{H}_{2} \mathrm{O}$.

All DNA was isolated from white blood cells of IDDM and nondiabetic donors. $4 \mathrm{ml}$ of blood collected in tubes with anticoagulants were incubated in $30 \mathrm{ml}$ hypotonic lysis buffer for $15 \mathrm{~min}$ on ice in order to lyse red blood cells. After hemolysis the hemolysates were centrifuged $30 \mathrm{~min}$ at $3500 \mathrm{rpm}$ at $4^{\circ} \mathrm{C}$ in order to pellet the leukocyte nuclei. The pellet was resuspended in

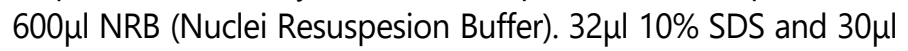
proteinase $\mathrm{K}$ solution was then added to the resuspended nuclei. After 2-12hr incubation at $55^{\circ} \mathrm{C}$ in a water bath (till DNA solution is translucent) $700 \mu \mathrm{l}$ Buffer-Saturated Phenol was added and vortexed to extract DNA. The mixture was centrifuged $5 \mathrm{~min}$ at $13000 \mathrm{rpm}$ at $4^{\circ} \mathrm{C}$. After the centrifugation the upper phase which contains DNA was transferred in new tubes and mixed with fresh $700 \mu l$ Buffer-Saturated Phenol by vortexing to further purify the DNA. After centrifugation at $13000 \mathrm{rpm}, 5 \mathrm{~min}$ at $4^{\circ} \mathrm{C}$ the upper phasewascollectedandmixedwith800 $\mu$ IPhenol:Cloroform:Isoamil Alcohol $(25: 24: 1, v / v)$ by vortexing. After the next centrifugation (5min at 13000 rpm at $4^{\circ} \mathrm{C}$ ) the DNA (upper phase) was transferred again in new tubes and DNA was precipitated by adding $1 \mathrm{ml}$ $100 \%$ ice cold ethanol and mixing. The precipitated DNA was pelleted by $5 \mathrm{~min}$ centrifugation at $13000 \mathrm{rpm}$ at $4^{\circ} \mathrm{C}$. The DNA pellet was washed by $0,5 \mathrm{ml} 70 \%$ ethanol and after drying the pellet was dissolved in $200 \mu \mathrm{l} \mathrm{H}_{2} \mathrm{O}$. The DNA samples were kept at $-80^{\circ} \mathrm{C}$ in aliquots for further use.

\section{Southern Blot Analysis}

\section{Preparation of TE buffer (10X)}

$50 \mathrm{ml}$ Tris- $\mathrm{HCl} 1 \mathrm{M} \mathrm{pH} 8,10 \mathrm{ml}$ EDTA $0,5 \mathrm{M}$ and $\mathrm{H}_{2} \mathrm{O}$ were added to a final volume of $500 \mathrm{ml}$.

After isolation of DNA from leucocytes by phenolchlorophorm-isoamylalcohol method, $20 \mu \mathrm{g}$ of the DNA were incubated with restriction enzymes (20U), at $65^{\circ} \mathrm{C}$ overnight in a 
water bath under constant shacking. The digested DNA was then loaded onto a 1,2\% agarose gel for electrophoretic separation. After electrophoresis the gel was acidified 30min in $0,25 \mathrm{~N} \mathrm{HCl}$, then twice $20 \mathrm{~min}$ in denaturation solution containing $9 \% \mathrm{NaCl}$ and $2 \% \mathrm{NaOH}(\mathrm{g} / \mathrm{v})$. After denaturation the gel was neutralized by washing twice $20 \mathrm{~min}$ in neutralization solution containing $9 \% \mathrm{NaCl}, 6 \%$ Tris and $0,018 \%$ EDTA ( $\mathrm{pH} 7,2)$. DNA was then transferred from the gel onto a nylon membrane by filter paper wick method overnight, and the next morning fixed for 5 min by UV-cross linking $(1200 \mu ; 254 \mathrm{~nm})$. After prehybridization of the membrane using $10 \mathrm{ml}$ prehybridization solution (containing 25ml Formamid; $10,4 \mathrm{ml} 20 \mathrm{x}$ SSC; $4,2 \mathrm{ml} 50 \mathrm{x}$ Denarth's; $2,1 \mathrm{ml} 1 \mathrm{M} \mathrm{NaH}_{2} \mathrm{PO}_{4}$ pH6,5; 4,2ml 10\% Glycine and $0,8 \mathrm{ml}(10 \mathrm{mg} / \mathrm{ml})$ salmon sperm DNA in $50 \mathrm{ml}$ end volume with $\mathrm{H}_{2} \mathrm{O}$ ) for 5 hours at $42^{\circ} \mathrm{C}$ in the cylinder, the membrane was hybridized by incubation with the ${ }^{32} \mathrm{P}$-radiolabeled DNA-probe using Ultrahyb hybridization solution $(10 \mathrm{ml})$ at $42^{\circ} \mathrm{C}$ overnight.

Probe labeling: for random primed labeling $11,5 \mu$ probe, (or 5-8 $\mu \mathrm{l}$ probe $+6,5-3,5 \mu \mathrm{l} \mathrm{H}_{2} \mathrm{O}$ up to $11,5 \mu \mathrm{l}$ end volume), and $2,5 \mu \mathrm{l}$ primer solution were boiled for $3 \mathrm{~min}$. The reaction was then cooled on ice, and $5 \mu$ l labeling buffer (-dCTP), $5 \mu \mathrm{l}$ ${ }^{32} \mathrm{PdCTP}$ and $1 \mu \mathrm{l} \mathrm{Klenov}$ were added before incubating the contents for $10 \mathrm{~min}$ at $37^{\circ} \mathrm{C}$ in a water bath. After $10 \mathrm{~min}$ synthesis in a water bath $5 \mu$ l salmon sperm DNA and $50 \mu \mathrm{ITE}$ buffer were added to the reaction mixture, which was then denatured in a boiling water bath for $3 \mathrm{~min}$, centrifuged to collect the condensate and placed on ice. The radio labeled probe was added to $10 \mathrm{ml}$ of fresh ULTRAhyb hybridization buffer, mixed thoroughly in the cylinder and then hybridized with the membrane.

After overnight hybridization blots were washed using NorthernMax High Stringency Wash solution \#1 (2x SSC, 0,1\% SDS; twice for $10 \mathrm{~min}$ at $45^{\circ} \mathrm{C}$ ), followed by NorthernMax Low Stringency Wash solution \#2 (0,1x SSC, 0,1\% SDS; twice for $10 \mathrm{~min}$ at $50^{\circ} \mathrm{C}$ ), and exposed for autoradiography to Kodak XAR5-Omat films at $-80^{\circ} \mathrm{C}$.

\section{Results and Discussion}

When searching for polymorphisms in the genes encoding CXCL9, CXCL10 and CXCL11 I found a difference in the IP-10 gene between patients with type 1 diabetes and control patients. What particularly attracted my attention is that over the small number of patients studied (10) in 9 there was a difference compared to the 9 controls (Fig.1).

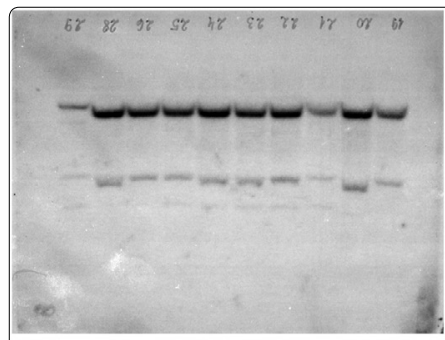

IP-10

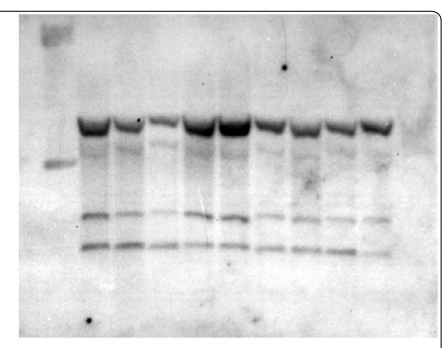

IP-10
IDDM

Figure 1. Southern blot analysis of genomic DNA from T1D and nondiabetics for polymorphisms in IP-10 gene.

The main hypothesis is that type 1 diabetes is the result of pro-inflammatory process of the pancreatic islets mainly via IP-10 and CXCR3 as a result of local viral infection. To the opinion of many authors CXCL10/CXCR3 system plays a critical role in the autoimmune beta cell destruction. Viral beta cell infections induce cytokines and CXCL10 expression, attracting CXCR3 and TLR4 expressing autoreactive immune cells inducing beta cell destruction and T1D.

The upregulation of CXCL10 and CXCR3 has been documented in many autoimmune disorders. Many studies have suggested that the CXCL10/CXCR3 axis plays a critical role in the autoimmune process and in $\beta$-cell destruction in Type 1 Diabetes. Serum CXCL10 level "Th1 chemokine" is high in T1D patients, and this suggests that CXCL10 may be a candidate for a predictive marker of T1D. Blocking of the CXCL10 chemokine expression in newly onset of diabetes seems to be a possible approach for the therapy of T1D [13].

Milicic et all. 2014 analyzed the level of, CXCR3(+) (Th1), CCR4(+) (Th2) T memory cells, IP-10(Th1) and TARC (thymus and activation-regulated chemokine)(Th2), in 51 first degree relatives (FDRs) of type 1 diabetics (T1D) (17 high risk FDRs $(\mathrm{GADA}(+), \mathrm{IA}-2(+)$ and 34 low risk FDRs (GADA(-), IA-2(-), 24 recent-onset T1D (R-T1D), and 18 healthy subjects. High risk FDRs showed higher levels of $\mathrm{CXCR3}(+)$ and lower level of CCR4(+) T memory cells compared to low risk. Simultaneously, both IP-10 and TARC levels were increased in high risk versus low risk FDRs. The level of CXCR3(+) T memory cells together with high levels of IP-10 might influence the risk for T1D [14].

My hypothesis is that to happen the autoimmune destruction, there must be some genetic differences in the gene coding at least one of both - receptor or ligand, which leads to a different way of interaction and stimulation. All individuals throughout their life are subjected to viral infections, but only a small percentage of the population react with such hypersensitivity and develop autoimmune diabetes. Genetic polymorphisms in the genes encoding IP-10 and it receptor CXCR3 on the surface of immune cells may be the reason for that.

I found a genetic polymorphism in the gene encoding the chemokine IP-10. This polymorphism was found only in patients with Type 1 diabetes, but not in nondiabetic patients. Investigating larger groups of people for the presence of this polymorphism to check for any link to type 1 diabetes is necessary. Identification of this polymorphism would give further explanation for its role in pro-inflammatory destruction of beta cells.

These investigations would contribute fighting diabetes on national and international level. By screening people for this polymorphism it would be possible to identify the predisposed to T1D individuals in early childhood and to prevent the development of T1D by trying different experimental preventive therapies.

Identification of this polymorphism would give more light and explanation for the reason and mechanism by which some individuals develop autoimmune diabetes. This 
knowledge would help to develop a strategy for prediction and prevention of T1D and to dissolve an important health problem.

Type 1 diabetes is a growing social problem. Until now there are many hypotheses, but none of them answers the questions why, when and how some individuals develop diabetes. Researchers are working on preventing the disease or preventing further destruction of the islet cells in people who are newly diagnosed but there's no known way to prevent type 1 diabetes.

The attempts to stop the process of autoimmune destruction of pancreatic beta cells by blocking $T$ cell receptors or antiviral vaccines delays but do not stop the disease. Since there is no know way to prevent T1D so far, the disease is not only incurable, but unpreventable and unpredictable. Researchers are still working towards fully understanding what causes or triggers T1D. Without fully understanding what triggers T1D remains difficult to prevent.

Researchers have made significant progress in understanding the cause of type 1 diabetes, and they're still working hard to figure out why certain viruses trigger it and why $T$ cells turn against beta cells. T1D is considered an inflammatory disease characterized by leukocyte infiltration at the islets of Langerhans. Chemokines are important participators in the recruitment of specific subpopulations of inflammatory cells into pancreas. The medical community wants to better understand the cases of diabetes in order to prevent it. Identification of this polymorphism would contribute for further scientific advance in disclosing the mechanism triggering T1D.

The viruses may trigger T1D, but the genes play important role in this process. Improved knowledge of gene polymorphisms of chemokines and their receptors could be useful to predict the onset of diabetes and define its progression. After the successful identification of this polymorphism there is a potential to continue the investigations further by developing tests for screening and identification of predisposed to T1D individuals and for research approaches focused on the development of preventive methods and approaches against T1D.

On the basis of the results would be developed predictive test for T1D predisposition, and working further we could search explanation how and when some individuals develop T1D.

Identification of this polymorphism will disclose the possible mechanism and reason for development of Type 1 diabetes. Revealing the possible mechanism of T1D development, will allow the scientists and medical specialists to predict who is predisposed to develop T1D and to work on developing strategies and approaches for its prevention and treatment.

\section{Conflict of Interest}

The authors declare that they have no competing interests.

\section{References}

1. Shimada A, Morimoto J, Kodama K, et al. Elevated serum IP-10 levels observed in type 1 diabetes. Diabetes Care. 2001; 24(3): 510-515. doi: 10.2337/diacare.24.3.510

2. Nicoletti F, Conget I, Mauro DM, et al. Serum concentrations of the interferon-gamma-inducible chemokine IP-10/CXCL10 are augmented in both newly-diagnosed Type I diabetes mellitus patients and subjects at risk of developing the disease. Diabetologia. 2002; 45(8): 1107-1110. doi: 10.1007/s00125-002-0879-5

3. Xin $Y$, Zhao $Y Q$, Zhao $Y X$, Zhang $L H$. The changes of serum interferoninducible protein-10 levels in children with type 1 diabetes mellitus. Zhonghua Er Ke Za Zhi. 2007; 45(11): 853-855.

4. Shigihara $T$, Oikawa $Y$, Kanazawa $Y$, et al. Significance of serum CXCL10/ IP-10 level in type 1 diabetes. J Autoimmun. 2006; 26(1): 66-71. doi: 10.1016/j.jaut.2005.09.027

5. Li D, Zhu SW, Liu DJ, Liu GL. Expression of interferon inducible protein-10 in pancreas of mice. World J. Gastroenterol. 2005; 4750-4752.

6. Uno S, Imagawa A, Saisho $K$, et al. Expression of chemokines, CXC chemokine ligand 10 (CXCL10) and CXCR3 in the inflamed islets of patients with recent-onset autoimmune type 1 diabetes. Endocr J. 2010; 57(11): 991-996.

7. Ken TC, Amirian N, Pagni PP, et al. Functional Redundancy of CXCR3/ CXCL10 Signaling in the Recruitment of Diabetogenic Cytotoxic T Lymphocytes to Pancreatic Islets in a Virally Induced Autoimmune Diabetes Model. Diabetes. 2013; 62(7): 2492-2499. doi: 10.2337/db121370

8. Shoichiro T, Nishida Y, Aida K, et al. Enterovirus Infection, CXC Chemokine Ligand 10 (CXCL10), and CXCR3 Circuit A Mechanism of Accelerated $\beta$-Cell Failure in Fulminant Type 1 Diabetes. Diabetes. 2009; 58(10): 2285-2291. doi: 10.2337/db09-0091

9. Roep BO, Kleijwegt FS, van Halteren AGS, et al. Islet inflammation and CXCL10 in recent-onset type 1 diabetes. Clin Exp Immunol. 2010; 159(3): 338-343. doi: 10.1111/j.1365-2249.2009.04087.x

10. Akira $S$, Oikawa $Y$, Yamada $Y$, Okubo $Y$, Narumi $S$. The Role of the CXCL10/CXCR3 System in Type 1 Diabetes. Rev Diabet Stud. 2009; 6(2): 81-84. doi: 10.1900/RDS.2009.6.81

11. Antonelli A, Ferrari SM, Corrado A, Ferrannini E, Fallahi P. CXCR3, CXCL10 and type 1 diabetes. Cytokine Growth Factor Rev. 2014; 25(1): 57-65. doi: 10.1016/j.cytogfr.2014.01.006

12. Schulthess FT, Paroni F, Sauter NS, et al. CXCL10 Impairs $\beta$ Cell Function and Viability in Diabetes through TLR4 Signaling. Cell Metabolism. 2009; 9(2): 125-139. doi: 10.1016/j.cmet.2009.01.003

13. Corrado A, Ferrari SM, Ferri C, Ferrannini E, Antonelli A, Fallahi P. Type 1 diabetes and (C-X-C motif) ligand (CXCL) 10 chemokine. Clin Ter. 2014; 165(2): 181-185. doi: 10.7471/CT.2014.1706

14. Milicic T, Jotic A, Markovic I, et al. High Risk First Degree Relatives of Type 1 Diabetics: An Association with Increases in CXCR3(+) T Memory Cells Reflecting an Enhanced Activity of Th1 Autoimmune Response. Int J Endocrinol. 2014; 2014: 9. doi: 10.1155/2014/589360 